\title{
The Debate Over State-Level Inequality: Transparent Method, Rules of Evidence, and Empirical Power
}

\author{
Timothy R. Wojan and Adam C. Maung*
}

\begin{abstract}
This article challenges the reliance on summary measures to inform trends in state level inequality. Since only a partial ordinal ranking of inequality is available to the researcher, one can never be certain if the results from a cardinal measure of inequality are unambiguous with respect to an implicit value orientation. In addition, we examine the robustness of results examining regional cost-of-living adjusted per capita income data. If cost-of-living differentials across states are substantial, then it is reasonable to expect that individuals with substantial components of unearned income most sensitive to these differentials will tend to reside in low-cost states-states which also tend to have lower incomes. Trends in the price adjusted earnings per worker series is examined to assess the power of analyses using per capita income to inform the process of regional income convergence.
\end{abstract}

\section{INTRODUCTION}

In a recent article Deller, Shields and Tomberlin (1996) examine trends in state income inequality after controlling for state specific cost-of-living differentials. The motivation for the article comes from various studies which have identified divergence in state per capita incomes in the 1980s after a long period of income convergence dating back as far as the $1880 \mathrm{~s}^{1}$. The convergence of incomes derives strong theoretical support from the neoclassical constructs of factor mobility, capital deepening and the resulting relative wage increases in poorer regions of the country. However, the purported period of income divergence suggests an empirical challenge to the long accepted process of income convergence. After analyzing cost-of-living adjusted state income data, the authors conclude that "the pattern of regional income convergence through the 1970 s followed by divergence in the 1980s are lost if spatial and temporal differences in regional prices are considered (p. 99)." The Deller et al. piece cautions that more valid data series should be used to examine the phenomenon before hastily concluding that the process of income convergence no longer characterizes the spatial economy.

\footnotetext{
*Wojan is a Post-Doctoral Research Associate at TVA Rural Studies, University of Kentucky. Maung was a Research Assistant in the Department of Agricultural Economics, University of Kentucky when this article was written. An earlier draft of this paper was presented at the 36th Annual Meetings of the Southern Regional Science Association in Memphis, TN in April of 1997. The authors wish to thank Steve Deller, Roger Stough and participants at that session as well as David Freshwater and three anonymous reviewers for constructive comments which improved the paper. All errors are the responsibility of the authors.

'See Barro and Sala-i-Martin (1992) and Garnick and Friedenberg (1982) regarding the long-term process of income convergence. The studies of Amos (1988, 1989), Coughlin and Mandelbaum (1988, 1989), Garnick (1990), Redman, Rowley and Angle (1992) and Renkow (1996) identify divergence (or non-convergence) of incomes in the 1980 s.
} 
By challenging the nearly universal convention that price differentials can be ignored in the examination of state-level inequality, the Deller et al. article opens up other widely accepted conventions in the literature to critique. Thus, the Deller et al. serves as a useful point of departure for the present discussion. While we recognize that conventions can serve as a more efficient shorthand for a literature, the danger is that these conventions may never be examined critically. For this article we restrict our attention to the dangers inherent in sole reliance on summary inequality measures to inform the inequality debate, especially when such analysis is extended to pronouncements regarding income convergence. We have tried to frame the argument to enliven an ongoing debate regarding the most appropriate methods to examine trends in regional inequality. Clearly, bringing more evidence to bear on the problem will not be productive until there is some agreement over what constitutes valid evidence.

Our critique is composed of two parts. First, the commonly accepted practice of relying on a particular summary measure of income inequality to inform trends toward convergence or divergence is challenged. Reliance on several inequality measures "to minimize the potential that...results are due to measurement construction" (Deller et al. p. 102) is also inadequate. We argue that more transparent results are available through the construction of Lorenz curves. If in comparing two distributions the Lorenz curves cross, then one can always find a valid summary measure that will rank the inequality of the two distributions differently (Dalton 1920, Atkinson 1970). Results by construction are in fact results of the implicit value orientation in various measures of inequality. Sole reliance on summary measures cannot easily provide 'clear and convincing' evidence (Gastwirth 1988, pp. 700-704) of either increasing or decreasing inequality. Since the array of valid inequality measures is large it will always be more parsimonious to construct Lorenz curves first rather than exhaust all possible sources of evidence through the computation of summary measures.

The second issue addresses the selection of appropriate data series to inform trends in increasing or decreasing inequality and its extension to the process of convergence. More specifically, we are concerned with increasing the power of statistical tests; i.e., that alternative hypotheses of close empirical association do not validate substantially different economic interpretations (McCloskey and Ziliak 1996). This is exactly the intent of the Deller et al. article in examining the importance of regional price differentials. The observed nominal pattern of increasing inequality could either represent a real increase in inequality or an increase in regional cost-of-living differentials. But while the article is successful as a research note demonstrating the importance of regional cost-of-living differentials changing through time, its policy conclusions are merely suggestive. More pointedly, the success of the technical exercise questions the appropriateness of the income per capita variable to inform the validity of the convergence hypothesis. If cost-of-living differentials across states are substantial, then it is reasonable to expect that individuals most sensitive (e.g., those on fixed incomes, or those most able to migrate due to a large component of unearned income) to these differentials 
will tend to reside in low-cost states-states which also tend to have lower incomes. While total income is arguably the best indicator of welfare, it may confuse tests of the convergence hypothesis. Earnings per worker introduces far fewer alternative explanations to the capital deepening and factor mobility foundations of the maintained hypothesis. A comparison of these two data series suggests that results of previous studies relying on income per capita to examine trends in statelevel equality may not be robust.

\section{THE IMPLICIT VALUE ORIENTATION IN INEQUALITY MEASUREMENT}

All single valued inequality measures provide only a partial ordering of income distributions. This is to be expected whenever a cardinal index is used to summarize an implicit welfare ordering. The result makes explicit the different value orientations embodied in summary inequality measures (see Blackwood and Lynch 1994 for a survey; also Allison 1978; Atkinson 1970 and 1983; and Champernowne 1974). Atkinson paraphrases Dalton (1920): "[U]nderlying any such measure is some concept of social welfare and it is with this concept that we should be concerned" (1970, p. 244). Given the subjective nature of selecting a particular social welfare function, it is surprising that economists have not made more use of the ordinal ranking of income distributions. Atkinson (1970) demonstrates that two income distributions can be unambiguously ranked with respect to (in)equality if the Lorenz curve of one lies everywhere above (below) that of the other. Although this condition is often violated-denying the possibility of an unambiguous ranking-its rejection would sensitize researchers to the fact that one can always find a summary inequality measure that will rank two distributions differently. Thus, our first exercise will be to determine if the ordinal ranking condition is violated for periods of interest using the cost-of-living adjusted income data from Deller et al. which forms the basis of our analysis.

The selection of inequality measures used in the Deller et al. article is justified largely on the basis of past use in the literature they are addressing. This effectively demonstrates that cost-of-living differences matter in the calculation of commonly used inequality measures. However, it is less convincing from the social welfare perspective especially since three of the measures are derived from the coefficient of variation-a measure which embodies a relatively conservative value orientation by placing equal weight on transfers over the entire distribution (Atkinson 1970). Alternatively, the Atkinson Index allows one to explicitly define the social welfare orientation by adjusting an "inequality aversion parameter." The second part of the exercise compares a specification of the Atkinson Index with the coefficient of variation using the cost-of-living adjusted data providing a concrete demonstration of how different value orientations lead to different conclusions regarding trends in regional inequality.

\section{COST-OF-LIVING ADJUSTMENTS}

It should be noted that the state cost-of-living adjustment used by Deller et al. is a rather crude price index. Given the substantial effort directed to the con- 
struction of valid purchasing power parity measures in international income convergence studies, it is surprising that the topic has received little attention in domestic studies (but see Eberts and Schweitzer 1994). It is the expenditure on immobile, nontradable services which introduces both the possibility of substantial regional cost-of-living differences as well as the difficulty of correcting for it. In fact, if using the non-adjusted income data abstracts from true regional cost-ofliving differentials undervaluing nominal income in poorer regions, then an argument can be made that the McMahon and Melton (1978) adjustment used in the Deller et al. article is prone to undue bias undervaluing income in wealthier regions in the 1980s. In deriving a regional adjustment, the median value of standard housing "emerges as by far the most significant predictor of geographical differences in the cost-of-living" (McMahon and Melton 1978, p. 324). However, this is erroneously used as a proxy for housing cost. Since 1983 the Bureau of Labor Statistics (BLS) has recognized the conceptual problem of the hybrid investment/ consumption character of housing expense by owner-occupants in constructing the national Consumer Price Index. Current 'best practice'

uses a "rental equivalence" approach to homeownership (the title of the CPI homeownership component is "owners' equivalent rent"). This is the same basic approach used in the inflation indexes of all advanced countries. Rental equivalence measures the change over time in the value of shelter services provided by homeownership. It is important to note that this approach measures the value to the homeowner of the daily consumption of a home's flow-ofservices (a place to fix meals, relax, entertain, garden, etc.) and not the value to the homeowner of an investment in a long-lived asset (home) that can fluctuate widely. (Emphasis in original, BLS 1995, p. 1).

Abraham and Hendershott (1992) examine the wide fluctuations in housing prices in some regions of the country during the 1980s. The inability of market fundamentals to explain a major share of variation in housing prices, combined with the substantial explanatory power of a lagged appreciation rate variable is consistent with the existence of speculative bubbles in Western and Northeastern housing markets.

Any cost-of-living deflator derived partly from housing values will be biased, effectively undervaluing income in those regions experiencing housing asset price appreciation as opposed to housing service price inflation. Rather than dismiss the McMahon and Melton index on this basis, we interpret it as a lower bound in the observed range of per capita income across states. The unadjusted series can be thought to comprise the upper bound of this observed range. As a lower bound it is least likely to identify an increase in inequality. It thus provides the hardest test of our argument that summary measures are unable to adequately identify patterns of increasing inequality for important subsets of states. For this reason the price adjusted per capita income series from the Deller et al. article based on the McMahon and Melton index is used throughout our analysis. However, it is important to reiterate that the regional price index used is imperfect, suggesting a highly productive area for future research (see Blanciforti 1996). 


\section{METHODS}

We begin the analysis by constructing Lorenz curves of the price adjusted data. ${ }^{2}$ To operationalize the fundamental question of whether a process of convergence in the 1970 s was replaced by a process of divergence in the 1980 s we calculate 1970,1980 and 1990 curves. To avoid the possibility that our results are influenced by spurious shocks in the data, a three-year moving average is calculated made up of the preceding, subsequent and target year of interest. The analysis gives equal weight to all of the states. ${ }^{3}$ The cumulative distribution of the income share which makes up the Lorenz curve is provided in Table 1. Our analysis also makes use of three summary measures of inequality. Their derivation is described below.

\section{COEFFICIENT OF VARIATION}

The coefficient of variation provides a link to the Deller et al. analysis. The same measure is applied to the unadjusted per capita income series used by Coughlin and Mandelbaum $(1988,1989)$ and Redman, Rowley and Angle (1992). The unweighted income variation, used in the studies cited above, is characterized by the following expression:

$$
\mathrm{V}_{\mathrm{uw}}=\frac{\sqrt{\frac{\sum_{\mathrm{i}=1}^{N}\left(\mathrm{y}_{\mathrm{i}}-\mathrm{y}\right)^{2}}{N}}}{\mathrm{y}}
$$

where $\mathrm{y}_{\mathrm{i}}$ and $\mathrm{y}$ refers to the state and mean income respectively and $\mathrm{N}$ denotes the number of states. We rely on the unweighted measure since an equal weighting is assigned to states in constructing the Lorenz curve.

\footnotetext{
${ }^{2}$ As the name suggests, a Lorenz curve is a graphical representation of an income distribution. More precisely, a Lorenz curve defines the ranked cumulative share of income with the share of income represented on the y-axis and the share of population represented on the $x$-axis. Thus, a Lorenz curve representing perfect equality would be a 45-degree line from the origin. In comparing two Lorenz curves across periods, we are most interested in whether or not these curves cross. Unfortunately, a graphical comparison of data used in this study is unsatisfactory due to the compression of the state per capita income distribution relative to, say, a personal income distribution. For this reason we present our Lorenz curve results in table format. The maintained assumption is one of convergence. Thus, the expectation is that latter period values will be greater (i.e., closer to the 45 degree perfect equality line) than earlier periods along corresponding rows. Where this expectation is contradicted, the value of the earlier period is in bold type.

${ }^{3}$ There are strong conceptual reasons to use unweighted measures in the analysis of regional inequality. First, weighting by population suggests that inequality with respect to the national population is the motivating interest. If so, then it is much more informative to examine the personal distribution of income for the nation as a whole. Analyzing mean levels for each state introduces an unnecessary intermediate step serving only to reduce the amount of relevant information in the analysis. Second, weighting by population may lead to erroneous conclusions regarding the pattern of inequality and how it informs the convergence process. There are two general ways that worker productivity can be increased leading to rising incomes in poorer regions. Capital can move into a region or labor can move out effectively increasing the capital-to-labor ratio. Assume that convergence is not the true process characterizing the economy, i.e., there is outmigration from poorer to richer regions but per capita incomes remain unchanged across regions. A weighted analysis will identify a reduction in regional inequality, and from the national perspective there is less regional inequality. But weighting leads to an incorrect inference on the convergence process.
} 


\section{ATKINSON INDEX}

Unlike many conventional inequality measures, the Atkinson index allows the researcher to define an explicit value orientation. The Atkinson index is given by:

$$
\mathrm{I}=1-\left[\Sigma\left(\mathrm{y}_{\mathrm{i}} / \mathrm{y}\right)^{(1-e)} \mathrm{f}_{\mathrm{i}}\right](1 /(1-\mathrm{e}))
$$

where $f_{i}$ denotes the proportion of the population in state $i$ (here assumed to be $1 / 48$ given the equal weights maintained throughout the analysis), and e symbolizes the inequality aversion parameter. In the index, the value of the parameter $e$ reflects an explicit welfare value orientation. As e rises, more weight is attached to transfers at the lower end of the distribution. The value e takes on 0 and $\infty$ in the extreme cases; $\mathrm{e}=0$ does not assign any value to how income is distributed, ranking distributions only according to total income while $e=\infty$ considers only transfers from the lowest income group in calculating I. The I index, more usefully termed the 'equally distributed equivalent measure,' is interpreted as the share of income that could be forsaken to maintain the current level of welfare if incomes were redistributed equally (Atkinson 1970).

\section{THEIL INDEX}

In the analysis we also find it informative to compute the Theil entropy index. The Deller et al. article identified the Theil-derived Nissan-Carter index as the one aberrant measure. We revert to measures in logs, consistent with the original Theil entropy measure, which allows additive decomposition of national inequality. The index is computed as

$$
J=\sum_{i=1}^{48} p_{i} \log \left(\frac{p_{i}}{y_{i}}\right)
$$

where $y_{i}$ and $p_{i}$ denote the income share of state $I$ and its population share which is assigned an equal share of $1 / 48$ in our computations. The index can be additively decomposed into inequality between regions and between states within regions (Theil 1989). Regional inequality is characterized as

$$
\mathrm{J}_{\mathrm{R}}=\sum_{\mathrm{g}=1}^{4} \mathrm{p}_{\mathrm{g}} \log \left(\frac{\mathrm{P}_{\mathrm{g}}}{\mathrm{Y}_{\mathrm{g}}}\right)
$$

where $Y_{g}$ and $P_{g}$ are the income and population share of region $g$. Using the same notation, the inequality among states in region $g$ can be expressed as

$$
\mathrm{J}_{\mathrm{g}}=\sum_{\mathrm{i}=1}^{48}\left(\frac{\mathrm{p}_{\mathrm{i}}}{\mathrm{P}_{\mathrm{g}}}\right) \log \left(\frac{\mathrm{p}_{\mathrm{i}} / \mathrm{P}_{\mathrm{g}}}{\mathrm{y}_{\mathrm{i}} / \mathrm{Y}_{\mathrm{g}}}\right)
$$

Finally, the Theil index J can be expressed in terms of the two components as

$$
\mathrm{J}=\mathrm{J}_{\mathrm{R}}+\sum_{\mathrm{g}=1}^{4} \mathrm{P}_{\mathrm{g}} \mathrm{J}_{\mathrm{g}}
$$


Thus the index is comprised of regional inequality and the population weighted average of inequality among states within regions.

\section{INCOME DATA RESULTS}

Our results from the Lorenz curve exercise provide a hint as to why researchers generally have avoided this step: the Lorenz curves for the 1970 and 1980 distributions as well as the 1980 and 1990 distributions cross (Table 1). No ordinal ranking exists for each of the ten-year intervals. However, our results also suggest that avoiding this step may be a false economy. An unambiguous result for the 1970 and 1990 interval is available and allows one to state unequivocally that price adjusted 1990 state per capita incomes are more equally distributed than 1970 state per capita incomes (Table 1).

More importantly, the Lorenz curves provide visual hints as to the trend over the entire distribution across the two decades. In the first decade, the 1980 curve is everywhere above the 1970 curve except for the two wealthiest states. That is, if we are not as concerned with inequality among wealthier states, then the 1980 distribution would likely be ranked higher than the 1970 distribution. Similarly, for the great majority of states the 1990 curve is above the 1980 curve. The critical difference is where these curves cross-the 1990 distribution lies below the 1980 distribution for the two poorest states. This example provides illustrative proof to the conjecture in Deller et al. "that there did indeed occur some level of divergence after 1978 (p. 109)." It also demonstrates that whether one characterizes the 1980 s as a process of divergence or convergence depends fundamentally on one's weighting of inequality across the distribution.

Our attempt to demonstrate this more concretely reinforces the shortcomings of sole reliance on summary inequality measures. Since the cumulative share of income table (Table 1) suggests that increasing inequality was limited to the very poorest states, we use Atkinson $\mathrm{e}=100$ to try to capture this phenomenon. ${ }^{4}$ The unweighted coefficient of variation is also computed. Despite the strong weight put on increasing inequality at the lower end of the distribution embodied in Atkinson e $=100$, the trend lines of the two measures through the 1970s and 1980s are fairly similar (Figure 1). ${ }^{5}$ And yet, both the Lorenz curve analysis and the aberrant Nissan-Carter entropy derived measure from the Deller et al. article suggest that some degree of divergence characterizes the 1980s.

The value of the Lorenz curve exercise (Table 1) becomes evident at this juncture. The two states commanding a lower share of per capita income in 1990

${ }^{4}$ This value is quite large relative to that used in the literature. However, in contrast to this other literature the current analysis examines mean per capita incomes which have a much tighter distribution than the personal income distributions commonly using the Atkinson Index.

${ }^{5}$ To derive a more objective comparison of the trends we estimated regression equations. The magnitude of the slope coefficients was very similar $(-0.0005$ for the Coefficient of Variation measure compared to -0.0004 for the Atkinson measure). However, the Atkinson estimate was not significantly different from zero and the estimated equation provided a poor fit to the data. The estimates are provided below (t-statistics in parentheses):
Coefficient of Variation $=1.216-0.0005^{*}$ Year
$\mathrm{R} 2=0.3604$
$\mathrm{F}=11.833$
Atkinson $(e=100)$
(3.735) (-3.44)
$=0.952-0.0004^{*}$ Year
$\mathrm{R} 2=0.253$
$\mathrm{F}=0.544$

(0.913) (-0.738) 
TABLE 1

Cumulative Income Share by Inverse Ranking of State Per Capita Income

\begin{tabular}{|c|c|c|c|c|c|c|c|}
\hline $\begin{array}{l}\text { Inverse } \\
\text { Rank }\end{array}$ & $\begin{array}{l}\text { Equal } \\
\text { Share }\end{array}$ & $\begin{array}{c}1970 \\
\text { Cumulative } \\
\text { Share }\end{array}$ & $\begin{array}{l}1970 \\
\text { State }\end{array}$ & $\begin{array}{c}1980 \\
\text { Cumulative } \\
\text { Share }\end{array}$ & $\begin{array}{l}1980 \\
\text { State }\end{array}$ & $\begin{array}{c}1990 \\
\text { Cumulative } \\
\text { Share }\end{array}$ & $\begin{array}{l}1990 \\
\text { State }\end{array}$ \\
\hline 1 & 0.02083 & 0.01583 & MS & 0.01663 & MS & 0.01645 & MS \\
\hline 2 & 0.04167 & 0.03305 & $\mathrm{AR}$ & 0.03454 & $\mathrm{ME}$ & 0.03443 & $\mathrm{AR}$ \\
\hline 3 & 0.0625 & 0.05083 & $\mathrm{AL}$ & 0.05245 & $\mathrm{AR}$ & 0.05246 & LA \\
\hline 4 & 0.08333 & 0.06880 & $\mathrm{ME}$ & 0.07040 & NC. & 0.07079 & NM \\
\hline 5 & 0.10417 & 0.08704 & LA & 0.08849 & SC & 0.08922 & WV \\
\hline 6 & 0.125 & 0.10534 & $\mathrm{SC}$ & 0.10665 & $\mathrm{AL}$ & 0.10793 & KY \\
\hline 7 & 0.14583 & 0.12378 & NC & 0.12530 & $\mathrm{TN}$ & 0.12671 & UT \\
\hline 8 & 0.16667 & 0.14230 & NM & 0.14412 & VT & 0.14560 & ND \\
\hline 9 & 0.1875 & 0.16093 & ND & 0.16305 & $\mathrm{KY}$ & 0.16461 & OK \\
\hline 10 & 0.20833 & 0.17963 & $\mathrm{TN}$ & 0.18211 & SD & 0.18377 & $\mathrm{ME}$ \\
\hline 11 & 0.22917 & 0.19834 & KY & 0.20140 & GA & 0.20294 & $\mathrm{AL}$ \\
\hline 12 & 0.25 & 0.21711 & $\mathrm{SD}$ & 0.22071 & WV & 0.22212 & MT \\
\hline 13 & 0.27083 & 0.23611 & WV & 0.24003 & NM & 0.24151 & $\mathrm{SC}$ \\
\hline 14 & 0.29167 & 0.25536 & VT & 0.25955 & UT & 0.26120 & NC \\
\hline 15 & 0.3125 & 0.27518 & VA & 0.27918 & ND & 0.28091 & VT \\
\hline 16 & 0.33333 & 0.29505 & GA & 0.29896 & RI & 0.30070 & SD \\
\hline 17 & 0.35417 & 0.31514 & UT & 0.31914 & LA & 0.32077 & TN \\
\hline 18 & 0.375 & 0.33535 & $\mathrm{NH}$ & 0.33932 & VA & 0.34088 & ID \\
\hline 19 & 0.39583 & 0.35557 & OK & 0.35952 & MA & 0.36105 & IA \\
\hline 20 & 0.41667 & 0.37594 & MT & 0.37978 & ID & 0.38142 & RI \\
\hline 21 & 0.4375 & 0.39639 & RI & 0.40042 & MT & 0.40199 & IN \\
\hline 22 & 0.45833 & 0.41723 & ID & 0.42108 & MO & 0.42274 & PA \\
\hline 23 & 0.47917 & 0.43817 & MA & 0.44181 & $\mathrm{NH}$ & 0.44365 & WI \\
\hline 24 & 0.5 & 0.45918 & $\mathrm{MO}$ & 0.46259 & NE & 0.46465 & $\mathrm{TX}$ \\
\hline 25 & 0.52083 & 0.48019 & $\mathrm{PA}$ & 0.48346 & $\mathrm{IN}$ & 0.48565 & $\mathrm{OH}$ \\
\hline 26 & 0.54167 & 0.50123 & $\mathrm{KS}$ & 0.50444 & $\mathrm{DE}$ & 0.50666 & $\mathrm{MO}$ \\
\hline 27 & 0.5625 & 0.52232 & IA & 0.52569 & PA & 0.52770 & $\mathrm{AZ}$ \\
\hline 28 & 0.58333 & 0.54353 & $\mathrm{NE}$ & 0.54699 & $\mathrm{MN}$ & 0.54878 & $\overline{N E}$ \\
\hline 29 & 0.60417 & 0.56476 & $\mathrm{MN}$ & 0.56836 & IA & 0.57001 & KS \\
\hline 30 & 0.625 & 0.58599 & $\mathrm{TX}$ & 0.58975 & $\mathrm{OH}$ & 0.59125 & OR \\
\hline 31 & 0.64583 & 0.60752 & WI & 0.61128 & WI & 0.61265 & GA \\
\hline 32 & 0.66667 & 0.62907 & IN & 0.63299 & OK & 0.63424 & WY \\
\hline 33 & 0.6875 & 0.65082 & $\mathrm{CO}$ & 0.65475 & NY & 0.65590 & $\mathrm{CA}$ \\
\hline 34 & 0.70833 & 0.67289 & NJ & 0.67661 & $\mathrm{AZ}$ & 0.67771 & $\mathrm{MN}$ \\
\hline 35 & 0.72917 & 0.69498 & OR & 0.69848 & $\mathrm{NJ}$ & 0.69955 & MI \\
\hline 36 & 0.75 & 0.71720 & $\mathrm{AZ}$ & 0.72052 & $\mathrm{CT}$ & 0.72142 & MA \\
\hline 37 & 0.77083 & 0.73952 & $\mathrm{OH}$ & 0.74260 & $\mathrm{KS}$ & 0.74337 & VA \\
\hline 38 & 0.79167 & 0.76188 & WY & 0.76484 & OR & 0.76539 & $\mathrm{DE}$ \\
\hline 39 & 0.8125 & 0.78425 & CT & 0.78713 & MD & 0.78768 & $\mathrm{CO}$ \\
\hline 40 & 0.83333 & 0.80717 & $\mathrm{CA}$ & 0.80943 & MI & 0.81004 & $\mathrm{NH}$ \\
\hline 41 & 0.85417 & 0.83027 & MI & 0.83194 & FL & 0.83280 & NY \\
\hline 42 & 0.875 & 0.85339 & $\mathrm{FL}$ & 0.85448 & CA & 0.85591 & IL \\
\hline 43 & 0.89583 & 0.87668 & WA & 0.87738 & $\mathrm{TX}$ & 0.87925 & WA \\
\hline 44 & 0.91667 & 0.90032 & MD & 0.90033 & $\mathrm{CO}$ & 0.90263 & NJ \\
\hline 45 & 0.9375 & 0.92404 & NY & 0.92348 & IL & 0.92617 & FL \\
\hline 46 & 0.95833 & 0.94824 & $\mathrm{DE}$ & 0.94725 & WA & 0.94998 & $\mathrm{CT}$ \\
\hline 47 & 0.97917 & 0.97246 & IL & 0.97355 & NV & 0.97474 & MD \\
\hline 48 & 1 & 1 & NV & 1 & WY & 1 & NV5 \\
\hline
\end{tabular}




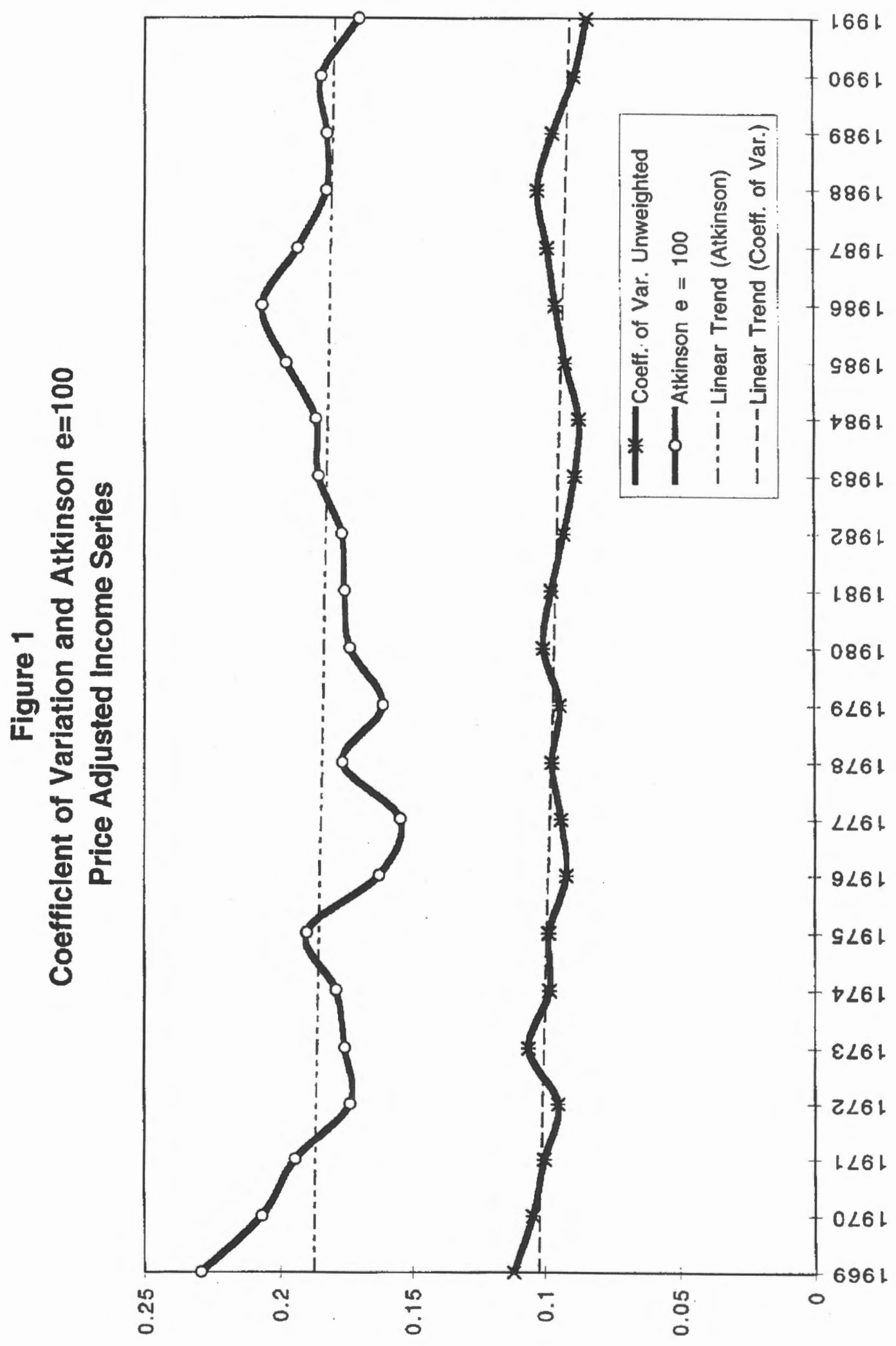


relative to 1980 (MS and AR) are in the South. In addition, some of the states demonstrating the most robust growth in income are also located in the South (e.g., VA, GA and FL). Since the Nissan-Carter measure in the Deller et al. article gives weight to increasing inequality within a region as well as between regions, increasing inequality due to the declining share of two southern states and the robust income growth of others may have overwhelmed the composite national measure. Figure 2 provides a decomposition of national inequality into between region and within region inequality. The decomposition demonstrates a persistent increase in inequality in the Southern states consistent with the Lorenz curve conjecture. While the spike in inequality in the West is the most dramatic feature of the graph it is the persistent increase in the Southeast component which is conceptually most troubling. From a national perspective the Nissan-Carter measure may be seen as aberrant. However, economists interested in Southern economic development could dismiss the measure only at their peril.

\section{THE COST-OF-LIVING ADJUSTMENT BASIS FOR EXAMINING EARNINGS TRENDS}

The results from the Deller et al. analysis themselves cast doubt on the usefulness of total income to examine trends toward regional convergence. If one is interested in identifying empirical regularities which are consistent with the capital deepening rationale of the theory, then the data series used should introduce as few potential alternative hypotheses as possible (McCloskey and Ziliak 1996). A data series which may introduce close alternatives with substantially different economic explanations will reduce the power of the test. That is, convergence may be confirmed but the test may not allow differentiating between a number of possible interpretations. In demonstrating that cost-of-living differentials do matter, the analysis gives greater credence to a number of alternative explanations.

From a regional science perspective it is important to recognize that some sources of income are better able to locate in low cost areas. Most importantly, this relocation of income is wholly independent of the process of capital deepening. For example, workers in high wage, high income states may choose to retire in lower income states where the cost-of-living is also substantially less. However, the strongest argument for using the earnings-per-worker series is that the earnings data do not exclude sources of income thought to be crucial to confirming the convergence hypothesis. ${ }^{6}$ The model is quite explicit in identifying increased wages through increased productivity due to higher rates of capital investment as

\footnotetext{
${ }^{6}$ Our initial analysis used earnings per capita which has been utilized in Renkow (1996) and Carlino and Mills (1996). However, comparison of the earnings per capita distribution with the income per capita distribution suggested an inherent weakness in the measure. The most dramatic example was the shift for Florida which was the fourth wealthiest state in 1990 using the income per capita series. However, using earnings per capita Florida fell below the median (19th in inverse rank). In both cases a variable unrelated to the income convergence through capital deepening hypothesis' was driving the ranking-unearned sources of income in the former and labor force participation rates in the latter. This points to the added value of routinely constructing Lorenz curves.
} 


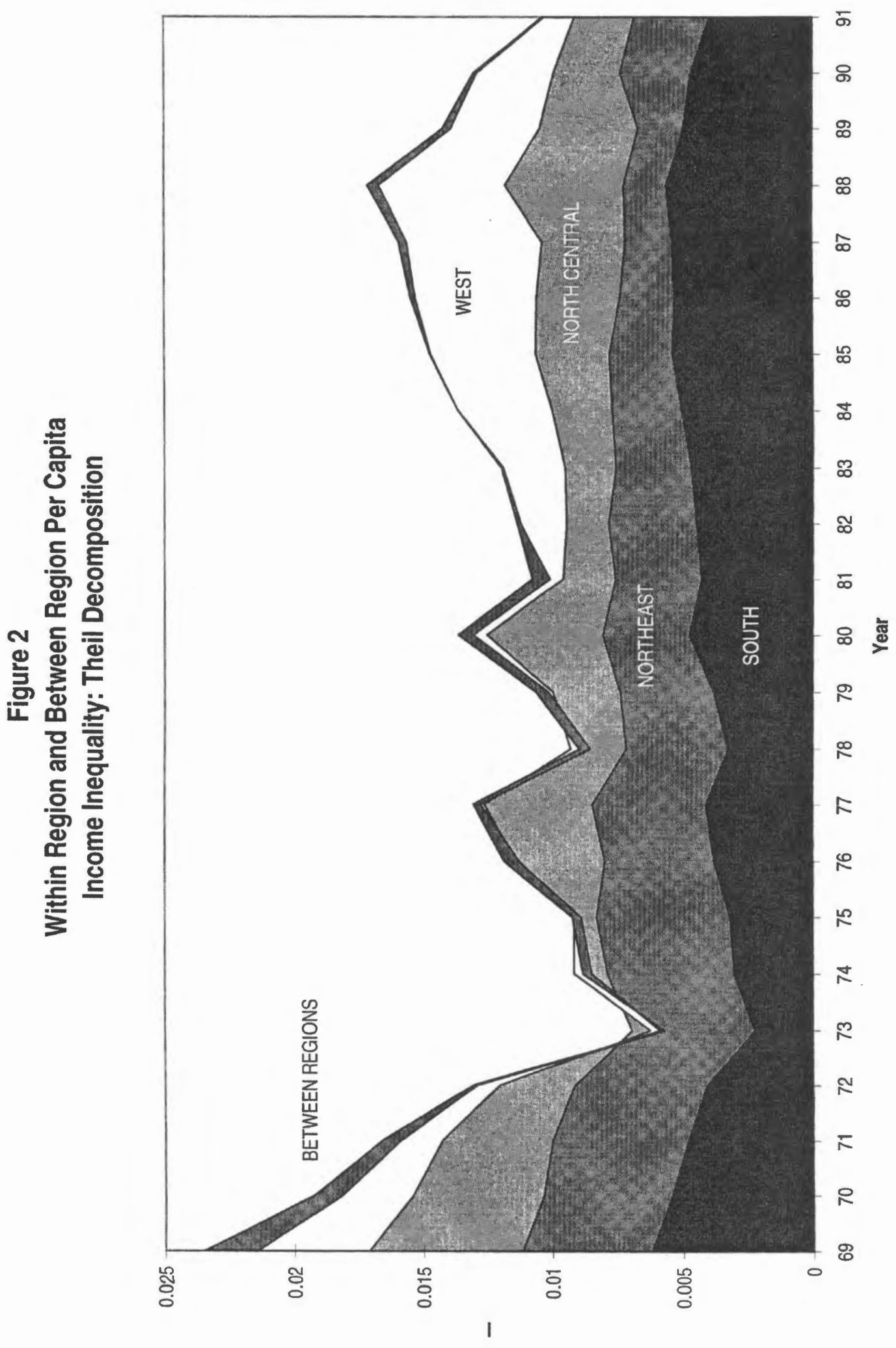


TABLE 2

Cumulative Earnings Share by Inverse Ranking of State Earnings Per Worker

\begin{tabular}{|c|c|c|c|c|c|c|c|}
\hline $\begin{array}{l}\text { Inverse } \\
\text { Rank }\end{array}$ & $\begin{array}{l}\text { Equal } \\
\text { Share }\end{array}$ & $\begin{array}{c}1970 \\
\text { Cumulative } \\
\text { Share }\end{array}$ & $\begin{array}{l}1970 \\
\text { State }\end{array}$ & $\begin{array}{c}1980 \\
\text { Cumulative } \\
\text { Share }\end{array}$ & $\begin{array}{l}1980 \\
\text { State }\end{array}$ & $\begin{array}{c}1990 \\
\text { Cumulative } \\
\text { Share }\end{array}$ & $\begin{array}{l}1990 \\
\text { State }\end{array}$ \\
\hline 1 & 0.02083 & 0.01744 & MS & 0.01756 & VT & 0.01746 & ND \\
\hline 2 & 0.04167 & 0.03509 & $\mathrm{ME}$ & 0.03519 & $\mathrm{ME}$ & 0.03543 & MT \\
\hline 3 & 0.0625 & 0.05296 & NH & 0.05290 & SD & 0.05350 & VT \\
\hline 4 & 0.08333 & 0.07099 & $\mathrm{AR}$ & 0.07081 & ND & 0.07193 & ME \\
\hline 5 & 0.10417 & 0.08913 & $\mathrm{NC}$ & 0.08883 & $\mathrm{NH}$ & 0.09055 & SD \\
\hline 6 & 0.125 & 0.10735 & $\mathrm{SD}$ & 0.10709 & $\mathrm{NC}$ & 0.10919 & IA \\
\hline 7 & 0.14583 & 0.12595 & VT & 0.12542 & RI & 0.12790 & MS \\
\hline 8 & 0.16667 & 0.14469 & $\mathrm{SC}$ & 0.14392 & MA & 0.14696 & $\mathrm{AR}$ \\
\hline 9 & 0.1875 & 0.16345 & VA & 0.16246 & MS & 0.16610 & KS \\
\hline 10 & 0.20833 & 0.18235 & RI & 0.18116 & VA & 0.18551 & RI \\
\hline 11 & 0.22917 & 0.20139 & ND & 0.20003 & $\mathrm{NE}$ & 0.20493 & OK \\
\hline 12 & 0.25 & 0.22063 & MA & 0.21923 & AR & 0.22456 & NE \\
\hline 13 & 0.27083 & 0.24000 & KS & 0.23844 & KS & 0.24442 & WY \\
\hline 14 & 0.29167 & 0.25944 & $\mathrm{TN}$ & 0.25778 & SC & 0.26431 & $\mathrm{NH}$ \\
\hline 15 & 0.3125 & 0.27914 & $\mathrm{AL}$ & 0.27718 & CT & 0.28422 & KY \\
\hline 16 & 0.33333 & 0.29908 & $\mathrm{CT}$ & 0.29692 & IA & 0.30416 & NM \\
\hline 17 & 0.35417 & 0.31912 & NE & 0.31682 & MT & 0.32428 & NC \\
\hline 18 & 0.375 & 0.33934 & IA & 0.33676 & $\mathrm{TN}$ & 0.34445 & WI \\
\hline 19 & 0.39583 & 0.35956 & GA & 0.35694 & $\mathrm{MN}$ & 0.36495 & VA \\
\hline 20 & 0.41667 & 0.37981 & $\mathrm{KY}$ & 0.37719 & MD & 0.38552 & MO \\
\hline 21 & 0.4375 & 0.40007 & OK & 0.39755 & GA & 0.40626 & SC \\
\hline 22 & 0.45833 & 0.42064 & NJ & 0.41794 & FL & 0.42705 & UT \\
\hline 23 & 0.47917 & 0.44142 & $\mathrm{CO}$ & 0.43841 & MO & 0.44787 & $\mathrm{CO}$ \\
\hline 24 & 0.5 & 0.46226 & WY & 0.45891 & NJ & 0.46869 & $\mathrm{TN}$ \\
\hline 25 & 0.52083 & 0.48315 & MT & 0.47958 & $\mathrm{AL}$ & 0.48964 & MA \\
\hline 26 & 0.54167 & 0.50411 & $\mathrm{MO}$ & 0.50024 & WI & 0.51065 & $\mathrm{MN}$ \\
\hline 27 & 0.5625 & 0.52519 & ID & 0.52110 & ID & 0.53172 & OR \\
\hline 28 & 0.58333 & 0.54632 & LA & 0.54233 & $\mathrm{CA}$ & 0.55284 & ID \\
\hline 29 & 0.60417 & 0.56768 & NM & 0.56362 & $\mathrm{KY}$ & 0.57403 & LA \\
\hline 30 & 0.625 & 0.58911 & WI & 0.58492 & $\mathrm{CO}$ & 0.59525 & PA \\
\hline 31 & 0.64583 & 0.61060 & PA & 0.60649 & NM & 0.61648 & $\mathrm{IN}$ \\
\hline 32 & 0.66667 & 0.63214 & $\mathrm{MN}$ & 0.62815 & OK & 0.63783 & $\mathrm{AL}$ \\
\hline 33 & 0.6875 & 0.65369 & FL & 0.65003 & OR & 0.65931 & FL \\
\hline 34 & 0.70833 & 0.67533 & MD & 0.67224 & IN & 0.68100 & WV \\
\hline 35 & 0.72917 & 0.69708 & TX & 0.69449 & $\mathrm{DE}$ & 0.70295 & $\mathrm{OH}$ \\
\hline 36 & 0.75 & 0.71901 & UT & 0.71678 & PA & 0.72495 & $\mathrm{AZ}$ \\
\hline 37 & 0.77083 & 0.74117 & OR & 0.73921 & NY & 0.74698 & $\mathrm{CT}$ \\
\hline 38 & 0.79167 & 0.76340 & $\mathrm{CA}$ & 0.76166 & UT & 0.76921 & $\mathrm{DE}$ \\
\hline 39 & 0.8125 & 0.78589 & $\mathrm{DE}$ & 0.78460 & $\mathrm{OH}$ & 0.79148 & MD \\
\hline 40 & 0.83333 & 0.80863 & IN & 0.80758 & $\mathrm{AZ}$ & 0.81375 & NJ \\
\hline 41 & 0.85417 & 0.83149 & WV & 0.83082 & LA & 0.83624 & CA \\
\hline 42 & 0.875 & 0.85443 & NY & 0.85410 & NV & 0.85888 & WA \\
\hline 43 & 0.89583 & 0.87758 & WA & 0.87765 & $\mathrm{TX}$ & 0.88159 & $\mathrm{TX}$ \\
\hline 44 & 0.91667 & 0.90105 & $\mathrm{AZ}$ & 0.90124 & WA & 0.90432 & GA \\
\hline 45 & 0.9375 & 0.92466 & $\mathrm{OH}$ & 0.92484 & IL & 0.92804 & IL \\
\hline 46 & 0.95833 & 0.94847 & IL & 0.94926 & WV & 0.95188 & NV \\
\hline 47 & 0.97917 & 0.97379 & NV & 0.97414 & WY & 0.97587 & NY \\
\hline 48 & 1 & 1.00000 & MI & 1.00000 & MI & 1.00000 & MI \\
\hline
\end{tabular}


This result has important implications for the practice of using summary inequality measures to inform processes of income convergence. While the trend in the Atkinson index appears volatile, its linear trend is relatively flat, suggesting neither an increase or decrease in inequality. That is, poorer states are not catching up with richer states in terms of earnings per worker given that the Atkinson index with an inequality aversion parameter of 100 puts greater weight on the lower part of the distribution. However, the fact that the linear trend of the unweighted coefficient of variation displays a statistically significant negative slope does suggest a decline in inequality. In other words, when equal weight is attached to transfers across the entire distribution, the summary measure indicates a decline in inequality. Consequently, the convergence implication suggested by the coefficient of variation measure is nullified by the fact that poorer states are not catching up with richer states as suggested by the Atkinson index.

\section{CONCLUSION}

The Deller et al. article provides suggestive evidence that regional and temporal price adjustments substantially alter trends in state per capita income identified by commonly used summary measures. It thus provides a counter to previous analyses identifying a process of regional income divergence. In this paper we have attempted to demonstrate that the convention in the literature of relying on summary inequality measures is supported by very weak rules of evidence. More transparent results are available to the researcher using a simple tool of inequality analysis such as the Lorenz curve. The Deller et al. article goes on to suggest the policy implications of examining the price adjusted data regarding income inequality generally and the process of income convergence more specifically. This paper takes issue with the policy implications derived from the analysis. Specifically, the price adjusted analysis provides insights toward selecting more appropriate data to examine the income convergence hypothesis. In fairness to the Deller et al. article it should be noted that the literature they rebut has also accepted the per capita income measure as appropriate to address issues of regional convergence.

Reliance on a single summary inequality measure (Amos 1988, 1989; Coughlin and Mandelbaum 1988, 1989; Garnick 1990; Redman, Rowley and Angle 1992) - or even the construction of several of the most commonly used measures (Deller et al. 1996) —cannot provide 'clear and convincing' evidence of a pattern of increasing or declining inequality. The approach used in the Deller et al. article allows the authors to conclude that the pattern of increasing inequality in the 1980s disappears for four of the five popular inequality measures used in the literature they rebut after controlling for regional cost-of-living differentials. The approach does not allow a more general statement.

Our results suggest there is much to be gained by routinely examining Lorenz curves to determine if an unambiguous statement can be made and, if not, identifying those parts of the distribution commanding a lesser share of total 
income. Most importantly, the examination of Lorenz curves allows examining information from the entire distribution in a meaningful way-a rare opportunity in most empirical work. This is an important addendum to a debate meant to inform best practice in the analysis of regional inequality.

We have demonstrated that the policy implications from articles which either identify a process of divergence or convergence through the use of summary measures should be used cautiously for a number of reasons. There is no theoretical or empirical support for equating decreases in regional income inequality using summary measures with regional income convergence. The process of regional convergence requires that poorer states catch up with richer states. This may or may not be indicated by an overall decrease in income inequality. Yet, even if one does identify a genuine empirical process of income convergence, the question remains whether the data series used is appropriate to inform the capital deepening hypothesis of the theory. In the Deller et al. article, the argument that price differentials do matter raises questions as to the appropriateness of the total income measure for testing the theoretical basis of convergence through capital deepening. Our analysis of earnings per worker data suggests that the widely accepted process of income convergence over the 1970s may be a spurious result driven by unearned sources of income.

As a research note the Deller et al. article is effective in demonstrating that state price differentials do matter in the examination of regional inequality. In challenging the conventional presumption that these differentials can be disregarded, the article opens up the literature on regional convergence to productive criticism and prods regional scientists to develop more valid regional price indexes. It is in this same vein that this paper is directed. By using more transparent analysis of income inequality - thus replacing the reliance on summary measures which may mask important details-researchers will be motivated to ask tough questions regarding the observed trends. This same transparency is likely to raise questions as to the appropriateness of the various measures used. This can only increase the power of empirical tests confirming or disconfirming a theory of substantial policy importance.

\section{REFERENCES}

Abraham, Jesse M., and Patric H. Hendershott. "Patterns and Determinants of Metropolitan House Prices, 1977 to 1991." In Real Estate and the Credit Crunch, Lynn E. Browne and Eric S. Rosengren, eds. Proceedings of a Conference Held at Melvin Village, New Hampshire, sponsored by the Federal Reserve Bank of Boston, September 1992.

Allison, Paul D. "Measures of Inequality." American Sociological Review 43(1978): 865-880.

Amos, O.M. "Unbalanced Regional Growth and Regional Income Inequality in Latter Stages of Development." Regional Science and Urban Economics 18 (1988): 549-566. 
Amos, O.M. "An Inquiry into the Causes of Increasing Regional Income Inequality in the Latter Stages of Development." The Review of Regional Studies. 19(1989): 1-12.

Atkinson, Anthony B. The Economics of Inequality. New York: Oxford University Press, 1983.

. "On the Measurement of Inequality." Journal of Economic Theory 2 (1970): 244-263.

Barro, Robert J., and Xavier Sala-i-Martin. "Convergence." Journal of Political Economy, 100(1992): 223-251.

Blackwood, D.L., and R.G. Lynch. "The Measurement of Inequality and Poverty: A Policy Maker's Guide to the Literature." World Development 22(1994):567-578. Blanciforti, Laura A. "Estimating Interregional Price Indexes: Opportunities and Pitfalls." Morgantown, WV: Regional Research Institute Working Paper 9621, 1996.

Bureau of Labor Statistics. "How the Consumer Price Index Measures Homeowners' Cost." Report available at http://stats.bls.gov/cpifact1.htm. 1995. Carlino, Gerald, and Leonard Mills. "Convergence and the U.S. States: A TimeSeries Analysis." Journal of Regional Science 36(1996): 597-616.

Champernowne, David. "A Comparison of Measures of Inequality of Income Distribution." The Economic Journal 84(1974): 787-816.

Coughlin, Cletus G., and Thomas R. Mandelbaum. "Why Have State Per Capita Incomes Diverged Lately?" Review of the Federal Reserve Bank of St. Louis 70(1988): 24-37.

. "Have Federal Spending and Taxation Contributed to the Divergence of State Per Capita Incomes in the 1980s?" Review of the Federal Reserve Bank of St. Louis 71(1989): 27-42.

Dalton, Hugh. "The Measurement of the Inequality of Incomes." Economic Journal 30(1920): 348-361.

Deller, Steven C., Martin Shields and David Tomberlin. "Price Differentials and Trends in State Income Levels: A Research Note." The Review of Regional Studies 26(1996): 99-113.

Eberts, Randall W., and Mark E. Schweitzer. "Regional Wage Convergence and Divergence: Adjusting Wages for Cost-of-Living Differences." Economic Review (Federal Reserve Bank of Cleveland) 20(1994): 26-37.

Garnick, D.H. "Accounting for Regional Differences in Per Capita Income Growth: An Update and Extension." Survey of Current Business (January 1990): 29-40.

Garnick, D.H., and H.L. Friedenberg. "Accounting for Regional Differences in Per Capita Personal Income Growth, 1929-1979." Survey of Current Business (September 1982): 24-34.

Gastwirth, Joseph L. Statistical Reasoning in Law and Public Policy, Volume 2: Tort Law, Evidence and Health. Boston: Academic Press, Inc., 1988.

McCloskey, Deirdre N., and Stephen T. Ziliak. "The Standard Error of Regressions." Journal of Economic Literature 34(1996): 97-114. 
McMahon, Walter W., and Carroll Melton. "Measuring Cost of Living Variation." Industrial Relations 17(1978): 324-332.

Redman, J.M., T.D. Rowley and J. Angle. "The Role of Nonmetropolitan Economic Performance in Rising Per Capita Income Differences Among the States." The Review of Regional Studies 22(1992): 155-168.

Renkow, Mitch. "Income Non-Convergence and Rural-Urban Earnings Differentials: Evidence from North Carolina." Southern Economic Journal 62(1996): 1016-1027.

Theil, Henri. "The Development of International Inequality 1960-1985." Journal of Econometrics 42(1989): 145-155. 
the principal mechanism of convergence. ${ }^{7}$ We are not suggesting that the policy focus should necessarily shift to convergence in earnings-per-worker. Rather, we suggest that the earnings data introduce the fewest number of close alternatives to the capital deepening rationale developed in the theory.

\section{EARNINGS DATA RESULTS}

The strongest result from the adjusted per capita income analysis is that 1990 incomes are more equally distributed than 1970 incomes. Is this result robust against using a more narrowly defined data series such as earnings-per-worker? The simple answer is 'Yes.' The Lorenz curve constructed for the three-year average of income around 1970 is everywhere below the 1990 Lorenz curve (Table 2).

This would appear to corroborate the per capita income analysis and the predictions of regional convergence. However, examining the 1970 and 1980 data suggests not only that the close alternative hypotheses introduced by the unearned sources of income are significant, but that they may be determinative of the observed trends in income inequality.

The well documented convergence in state incomes over the $1970 \mathrm{~s}$ is strongly challenged by the Lorenz curve analysis when examining earnings per worker. It is only for a handful of the wealthiest states that 1970 income appeared more equally distributed. However, this result changes dramatically in examining the earnings data. While earnings-per-worker among the two poorest states (and that claimed by the six richest states) suggest a more equal distribution in 1980 compared to 1970; everywhere else the 1970 distribution dominates 1980. Again, it must be reiterated that there is wide agreement in the literature that per capita state incomes converged over the 1970s. These results were corroborated in the price adjusted analysis of Deller et al. (1996). But the earnings data provide disconfirming evidence of the convergence through capital deepening hypothesis for the 1970s. As a measure introducing far fewer alternative explanations of the presumed convergence result, the earnings data suggest that the test of capital deepening using the per capita income measure may be spurious.

Quantifying yearly changes in earnings inequality using summary measures is very informative. In examining per capita income inequality, the coefficient of variation and the Atkinson $\mathrm{e}=100$ index demonstrated very similar trends. This is not the case in examining per worker earnings. The coefficient of variation measure (Figure 3) is downward sloping over the period despite an increase in volatility relative to the income series. However, the Atkinson measure, characterized by large year-to-year volatility, indicates a very flat trend over this period. ${ }^{8}$

\footnotetext{
${ }^{7}$ Conceptually, dividend incomes capture a part of the capital deepening story as returns on capital investment. However, exclusion of dividend data is justified on the grounds that it is impossible to match the receipt of dividend payments in a state to the actual capital investment in a state.

${ }^{8}$ Comparing regression equations corresponding to the trend lines is again very informative. This time the magnitude of the estimates differs substantially. Although both estimates are negative the Atkinson estimate is very close to zero relative to the Coefficient of Variation estimate. But the very poor fit of the Atkinson equation cautions against making any substantive inferences. The statistics are provided below ( $t$-statistics in parentheses): Coefficient of Variation $=2.014-0.00097^{*}$ Year Atkinson $(\mathrm{e}=100) \quad=0.201-0.000026^{*}$ Year $\mathrm{R} 2=0.5159$ $\mathrm{R} 2=0.00001$ $\mathrm{F}=22.380(0.406)(-4.73)$

$\mathrm{F}=0.001$
} (0.12) $(-0.031)$ 
TABLE 2

Cumulative Earnings Share by Inverse Ranking of State Earnings Per Worker

\begin{tabular}{|c|c|c|c|c|c|c|c|}
\hline $\begin{array}{l}\text { Inverse } \\
\text { Rank }\end{array}$ & $\begin{array}{l}\text { Equal } \\
\text { Share }\end{array}$ & $\begin{array}{c}1970 \\
\text { Cumulative } \\
\text { Share }\end{array}$ & $\begin{array}{l}1970 \\
\text { State }\end{array}$ & $\begin{array}{c}1980 \\
\text { Cumulative } \\
\text { Share }\end{array}$ & $\begin{array}{l}1980 \\
\text { State }\end{array}$ & $\begin{array}{c}1990 \\
\text { Cumulative } \\
\text { Share }\end{array}$ & $\begin{array}{l}1990 \\
\text { State }\end{array}$ \\
\hline 1 & 0.02083 & 0.01744 & MS & 0.01756 & VT & 0.01746 & ND \\
\hline 2 & 0.04167 & 0.03509 & $\mathrm{ME}$ & 0.03519 & $\mathrm{ME}$ & 0.03543 & MT \\
\hline 3 & 0.0625 & 0.05296 & NH & 0.05290 & SD & 0.05350 & VT \\
\hline 4 & 0.08333 & 0.07099 & $\mathrm{AR}$ & 0.07081 & ND & 0.07193 & ME \\
\hline 5 & 0.10417 & 0.08913 & $\mathrm{NC}$ & 0.08883 & $\mathrm{NH}$ & 0.09055 & SD \\
\hline 6 & 0.125 & 0.10735 & $\mathrm{SD}$ & 0.10709 & $\mathrm{NC}$ & 0.10919 & IA \\
\hline 7 & 0.14583 & 0.12595 & VT & 0.12542 & RI & 0.12790 & MS \\
\hline 8 & 0.16667 & 0.14469 & $\mathrm{SC}$ & 0.14392 & MA & 0.14696 & $\mathrm{AR}$ \\
\hline 9 & 0.1875 & 0.16345 & VA & 0.16246 & MS & 0.16610 & KS \\
\hline 10 & 0.20833 & 0.18235 & RI & 0.18116 & VA & 0.18551 & RI \\
\hline 11 & 0.22917 & 0.20139 & ND & 0.20003 & $\mathrm{NE}$ & 0.20493 & OK \\
\hline 12 & 0.25 & 0.22063 & MA & 0.21923 & AR & 0.22456 & NE \\
\hline 13 & 0.27083 & 0.24000 & KS & 0.23844 & KS & 0.24442 & WY \\
\hline 14 & 0.29167 & 0.25944 & $\mathrm{TN}$ & 0.25778 & SC & 0.26431 & $\mathrm{NH}$ \\
\hline 15 & 0.3125 & 0.27914 & $\mathrm{AL}$ & 0.27718 & CT & 0.28422 & KY \\
\hline 16 & 0.33333 & 0.29908 & $\mathrm{CT}$ & 0.29692 & IA & 0.30416 & NM \\
\hline 17 & 0.35417 & 0.31912 & NE & 0.31682 & MT & 0.32428 & NC \\
\hline 18 & 0.375 & 0.33934 & IA & 0.33676 & $\mathrm{TN}$ & 0.34445 & WI \\
\hline 19 & 0.39583 & 0.35956 & GA & 0.35694 & $\mathrm{MN}$ & 0.36495 & VA \\
\hline 20 & 0.41667 & 0.37981 & $\mathrm{KY}$ & 0.37719 & MD & 0.38552 & MO \\
\hline 21 & 0.4375 & 0.40007 & OK & 0.39755 & GA & 0.40626 & SC \\
\hline 22 & 0.45833 & 0.42064 & NJ & 0.41794 & FL & 0.42705 & UT \\
\hline 23 & 0.47917 & 0.44142 & $\mathrm{CO}$ & 0.43841 & MO & 0.44787 & $\mathrm{CO}$ \\
\hline 24 & 0.5 & 0.46226 & WY & 0.45891 & NJ & 0.46869 & $\mathrm{TN}$ \\
\hline 25 & 0.52083 & 0.48315 & MT & 0.47958 & $\mathrm{AL}$ & 0.48964 & MA \\
\hline 26 & 0.54167 & 0.50411 & $\mathrm{MO}$ & 0.50024 & WI & 0.51065 & $\mathrm{MN}$ \\
\hline 27 & 0.5625 & 0.52519 & ID & 0.52110 & ID & 0.53172 & OR \\
\hline 28 & 0.58333 & 0.54632 & LA & 0.54233 & $\mathrm{CA}$ & 0.55284 & ID \\
\hline 29 & 0.60417 & 0.56768 & NM & 0.56362 & $\mathrm{KY}$ & 0.57403 & LA \\
\hline 30 & 0.625 & 0.58911 & WI & 0.58492 & $\mathrm{CO}$ & 0.59525 & PA \\
\hline 31 & 0.64583 & 0.61060 & PA & 0.60649 & NM & 0.61648 & $\mathrm{IN}$ \\
\hline 32 & 0.66667 & 0.63214 & $\mathrm{MN}$ & 0.62815 & OK & 0.63783 & $\mathrm{AL}$ \\
\hline 33 & 0.6875 & 0.65369 & FL & 0.65003 & OR & 0.65931 & FL \\
\hline 34 & 0.70833 & 0.67533 & MD & 0.67224 & IN & 0.68100 & WV \\
\hline 35 & 0.72917 & 0.69708 & TX & 0.69449 & $\mathrm{DE}$ & 0.70295 & $\mathrm{OH}$ \\
\hline 36 & 0.75 & 0.71901 & UT & 0.71678 & PA & 0.72495 & $\mathrm{AZ}$ \\
\hline 37 & 0.77083 & 0.74117 & OR & 0.73921 & NY & 0.74698 & $\mathrm{CT}$ \\
\hline 38 & 0.79167 & 0.76340 & $\mathrm{CA}$ & 0.76166 & UT & 0.76921 & $\mathrm{DE}$ \\
\hline 39 & 0.8125 & 0.78589 & $\mathrm{DE}$ & 0.78460 & $\mathrm{OH}$ & 0.79148 & MD \\
\hline 40 & 0.83333 & 0.80863 & IN & 0.80758 & $\mathrm{AZ}$ & 0.81375 & NJ \\
\hline 41 & 0.85417 & 0.83149 & WV & 0.83082 & LA & 0.83624 & CA \\
\hline 42 & 0.875 & 0.85443 & NY & 0.85410 & NV & 0.85888 & WA \\
\hline 43 & 0.89583 & 0.87758 & WA & 0.87765 & $\mathrm{TX}$ & 0.88159 & $\mathrm{TX}$ \\
\hline 44 & 0.91667 & 0.90105 & $\mathrm{AZ}$ & 0.90124 & WA & 0.90432 & GA \\
\hline 45 & 0.9375 & 0.92466 & $\mathrm{OH}$ & 0.92484 & IL & 0.92804 & IL \\
\hline 46 & 0.95833 & 0.94847 & IL & 0.94926 & WV & 0.95188 & NV \\
\hline 47 & 0.97917 & 0.97379 & NV & 0.97414 & WY & 0.97587 & NY \\
\hline 48 & 1 & 1.00000 & MI & 1.00000 & MI & 1.00000 & MI \\
\hline
\end{tabular}


TABLE 2

Cumulative Earnings Share by Inverse Ranking of State Earnings Per Worker

\begin{tabular}{|c|c|c|c|c|c|c|c|}
\hline $\begin{array}{l}\text { Inverse } \\
\text { Rank }\end{array}$ & $\begin{array}{l}\text { Equal } \\
\text { Share }\end{array}$ & $\begin{array}{c}1970 \\
\text { Cumulative } \\
\text { Share }\end{array}$ & $\begin{array}{l}1970 \\
\text { State }\end{array}$ & $\begin{array}{c}1980 \\
\text { Cumulative } \\
\text { Share }\end{array}$ & $\begin{array}{l}1980 \\
\text { State }\end{array}$ & $\begin{array}{c}1990 \\
\text { Cumulative } \\
\text { Share }\end{array}$ & $\begin{array}{l}1990 \\
\text { State }\end{array}$ \\
\hline 1 & 0.02083 & 0.01744 & MS & 0.01756 & VT & 0.01746 & ND \\
\hline 2 & 0.04167 & 0.03509 & $\mathrm{ME}$ & 0.03519 & $\mathrm{ME}$ & 0.03543 & MT \\
\hline 3 & 0.0625 & 0.05296 & NH & 0.05290 & SD & 0.05350 & VT \\
\hline 4 & 0.08333 & 0.07099 & $\mathrm{AR}$ & 0.07081 & ND & 0.07193 & ME \\
\hline 5 & 0.10417 & 0.08913 & $\mathrm{NC}$ & 0.08883 & $\mathrm{NH}$ & 0.09055 & SD \\
\hline 6 & 0.125 & 0.10735 & $\mathrm{SD}$ & 0.10709 & $\mathrm{NC}$ & 0.10919 & IA \\
\hline 7 & 0.14583 & 0.12595 & VT & 0.12542 & RI & 0.12790 & MS \\
\hline 8 & 0.16667 & 0.14469 & $\mathrm{SC}$ & 0.14392 & MA & 0.14696 & $\mathrm{AR}$ \\
\hline 9 & 0.1875 & 0.16345 & VA & 0.16246 & MS & 0.16610 & KS \\
\hline 10 & 0.20833 & 0.18235 & RI & 0.18116 & VA & 0.18551 & RI \\
\hline 11 & 0.22917 & 0.20139 & ND & 0.20003 & $\mathrm{NE}$ & 0.20493 & OK \\
\hline 12 & 0.25 & 0.22063 & MA & 0.21923 & AR & 0.22456 & NE \\
\hline 13 & 0.27083 & 0.24000 & KS & 0.23844 & KS & 0.24442 & WY \\
\hline 14 & 0.29167 & 0.25944 & $\mathrm{TN}$ & 0.25778 & SC & 0.26431 & $\mathrm{NH}$ \\
\hline 15 & 0.3125 & 0.27914 & $\mathrm{AL}$ & 0.27718 & CT & 0.28422 & KY \\
\hline 16 & 0.33333 & 0.29908 & $\mathrm{CT}$ & 0.29692 & IA & 0.30416 & NM \\
\hline 17 & 0.35417 & 0.31912 & NE & 0.31682 & MT & 0.32428 & NC \\
\hline 18 & 0.375 & 0.33934 & IA & 0.33676 & $\mathrm{TN}$ & 0.34445 & WI \\
\hline 19 & 0.39583 & 0.35956 & GA & 0.35694 & $\mathrm{MN}$ & 0.36495 & VA \\
\hline 20 & 0.41667 & 0.37981 & $\mathrm{KY}$ & 0.37719 & MD & 0.38552 & MO \\
\hline 21 & 0.4375 & 0.40007 & OK & 0.39755 & GA & 0.40626 & SC \\
\hline 22 & 0.45833 & 0.42064 & NJ & 0.41794 & FL & 0.42705 & UT \\
\hline 23 & 0.47917 & 0.44142 & $\mathrm{CO}$ & 0.43841 & MO & 0.44787 & $\mathrm{CO}$ \\
\hline 24 & 0.5 & 0.46226 & WY & 0.45891 & NJ & 0.46869 & $\mathrm{TN}$ \\
\hline 25 & 0.52083 & 0.48315 & MT & 0.47958 & $\mathrm{AL}$ & 0.48964 & MA \\
\hline 26 & 0.54167 & 0.50411 & $\mathrm{MO}$ & 0.50024 & WI & 0.51065 & $\mathrm{MN}$ \\
\hline 27 & 0.5625 & 0.52519 & ID & 0.52110 & ID & 0.53172 & OR \\
\hline 28 & 0.58333 & 0.54632 & LA & 0.54233 & $\mathrm{CA}$ & 0.55284 & ID \\
\hline 29 & 0.60417 & 0.56768 & NM & 0.56362 & $\mathrm{KY}$ & 0.57403 & LA \\
\hline 30 & 0.625 & 0.58911 & WI & 0.58492 & $\mathrm{CO}$ & 0.59525 & PA \\
\hline 31 & 0.64583 & 0.61060 & PA & 0.60649 & NM & 0.61648 & $\mathrm{IN}$ \\
\hline 32 & 0.66667 & 0.63214 & $\mathrm{MN}$ & 0.62815 & OK & 0.63783 & $\mathrm{AL}$ \\
\hline 33 & 0.6875 & 0.65369 & FL & 0.65003 & OR & 0.65931 & FL \\
\hline 34 & 0.70833 & 0.67533 & MD & 0.67224 & IN & 0.68100 & WV \\
\hline 35 & 0.72917 & 0.69708 & TX & 0.69449 & $\mathrm{DE}$ & 0.70295 & $\mathrm{OH}$ \\
\hline 36 & 0.75 & 0.71901 & UT & 0.71678 & PA & 0.72495 & $\mathrm{AZ}$ \\
\hline 37 & 0.77083 & 0.74117 & OR & 0.73921 & NY & 0.74698 & $\mathrm{CT}$ \\
\hline 38 & 0.79167 & 0.76340 & $\mathrm{CA}$ & 0.76166 & UT & 0.76921 & $\mathrm{DE}$ \\
\hline 39 & 0.8125 & 0.78589 & $\mathrm{DE}$ & 0.78460 & $\mathrm{OH}$ & 0.79148 & MD \\
\hline 40 & 0.83333 & 0.80863 & IN & 0.80758 & $\mathrm{AZ}$ & 0.81375 & NJ \\
\hline 41 & 0.85417 & 0.83149 & WV & 0.83082 & LA & 0.83624 & CA \\
\hline 42 & 0.875 & 0.85443 & NY & 0.85410 & NV & 0.85888 & WA \\
\hline 43 & 0.89583 & 0.87758 & WA & 0.87765 & $\mathrm{TX}$ & 0.88159 & $\mathrm{TX}$ \\
\hline 44 & 0.91667 & 0.90105 & $\mathrm{AZ}$ & 0.90124 & WA & 0.90432 & GA \\
\hline 45 & 0.9375 & 0.92466 & $\mathrm{OH}$ & 0.92484 & IL & 0.92804 & IL \\
\hline 46 & 0.95833 & 0.94847 & IL & 0.94926 & WV & 0.95188 & NV \\
\hline 47 & 0.97917 & 0.97379 & NV & 0.97414 & WY & 0.97587 & NY \\
\hline 48 & 1 & 1.00000 & MI & 1.00000 & MI & 1.00000 & MI \\
\hline
\end{tabular}


This result has important implications for the practice of using summary inequality measures to inform processes of income convergence. While the trend in the Atkinson index appears volatile, its linear trend is relatively flat, suggesting neither an increase or decrease in inequality. That is, poorer states are not catching up with richer states in terms of earnings per worker given that the Atkinson index with an inequality aversion parameter of 100 puts greater weight on the lower part of the distribution. However, the fact that the linear trend of the unweighted coefficient of variation displays a statistically significant negative slope does suggest a decline in inequality. In other words, when equal weight is attached to transfers across the entire distribution, the summary measure indicates a decline in inequality. Consequently, the convergence implication suggested by the coefficient of variation measure is nullified by the fact that poorer states are not catching up with richer states as suggested by the Atkinson index.

\section{CONCLUSION}

The Deller et al. article provides suggestive evidence that regional and temporal price adjustments substantially alter trends in state per capita income identified by commonly used summary measures. It thus provides a counter to previous analyses identifying a process of regional income divergence. In this paper we have attempted to demonstrate that the convention in the literature of relying on summary inequality measures is supported by very weak rules of evidence. More transparent results are available to the researcher using a simple tool of inequality analysis such as the Lorenz curve. The Deller et al. article goes on to suggest the policy implications of examining the price adjusted data regarding income inequality generally and the process of income convergence more specifically. This paper takes issue with the policy implications derived from the analysis. Specifically, the price adjusted analysis provides insights toward selecting more appropriate data to examine the income convergence hypothesis. In fairness to the Deller et al. article it should be noted that the literature they rebut has also accepted the per capita income measure as appropriate to address issues of regional convergence.

Reliance on a single summary inequality measure (Amos 1988, 1989; Coughlin and Mandelbaum 1988, 1989; Garnick 1990; Redman, Rowley and Angle 1992) - or even the construction of several of the most commonly used measures (Deller et al. 1996) —cannot provide 'clear and convincing' evidence of a pattern of increasing or declining inequality. The approach used in the Deller et al. article allows the authors to conclude that the pattern of increasing inequality in the 1980s disappears for four of the five popular inequality measures used in the literature they rebut after controlling for regional cost-of-living differentials. The approach does not allow a more general statement.

Our results suggest there is much to be gained by routinely examining Lorenz curves to determine if an unambiguous statement can be made and, if not, identifying those parts of the distribution commanding a lesser share of total 
income. Most importantly, the examination of Lorenz curves allows examining information from the entire distribution in a meaningful way-a rare opportunity in most empirical work. This is an important addendum to a debate meant to inform best practice in the analysis of regional inequality.

We have demonstrated that the policy implications from articles which either identify a process of divergence or convergence through the use of summary measures should be used cautiously for a number of reasons. There is no theoretical or empirical support for equating decreases in regional income inequality using summary measures with regional income convergence. The process of regional convergence requires that poorer states catch up with richer states. This may or may not be indicated by an overall decrease in income inequality. Yet, even if one does identify a genuine empirical process of income convergence, the question remains whether the data series used is appropriate to inform the capital deepening hypothesis of the theory. In the Deller et al. article, the argument that price differentials do matter raises questions as to the appropriateness of the total income measure for testing the theoretical basis of convergence through capital deepening. Our analysis of earnings per worker data suggests that the widely accepted process of income convergence over the 1970s may be a spurious result driven by unearned sources of income.

As a research note the Deller et al. article is effective in demonstrating that state price differentials do matter in the examination of regional inequality. In challenging the conventional presumption that these differentials can be disregarded, the article opens up the literature on regional convergence to productive criticism and prods regional scientists to develop more valid regional price indexes. It is in this same vein that this paper is directed. By using more transparent analysis of income inequality - thus replacing the reliance on summary measures which may mask important details-researchers will be motivated to ask tough questions regarding the observed trends. This same transparency is likely to raise questions as to the appropriateness of the various measures used. This can only increase the power of empirical tests confirming or disconfirming a theory of substantial policy importance.

\section{REFERENCES}

Abraham, Jesse M., and Patric H. Hendershott. "Patterns and Determinants of Metropolitan House Prices, 1977 to 1991." In Real Estate and the Credit Crunch, Lynn E. Browne and Eric S. Rosengren, eds. Proceedings of a Conference Held at Melvin Village, New Hampshire, sponsored by the Federal Reserve Bank of Boston, September 1992.

Allison, Paul D. "Measures of Inequality." American Sociological Review 43(1978): 865-880.

Amos, O.M. "Unbalanced Regional Growth and Regional Income Inequality in Latter Stages of Development." Regional Science and Urban Economics 18 (1988): 549-566. 
Amos, O.M. "An Inquiry into the Causes of Increasing Regional Income Inequality in the Latter Stages of Development." The Review of Regional Studies. 19(1989): 1-12.

Atkinson, Anthony B. The Economics of Inequality. New York: Oxford University Press, 1983.

. "On the Measurement of Inequality." Journal of Economic Theory 2 (1970): 244-263.

Barro, Robert J., and Xavier Sala-i-Martin. "Convergence." Journal of Political Economy, 100(1992): 223-251.

Blackwood, D.L., and R.G. Lynch. "The Measurement of Inequality and Poverty: A Policy Maker's Guide to the Literature." World Development 22(1994):567-578. Blanciforti, Laura A. "Estimating Interregional Price Indexes: Opportunities and Pitfalls." Morgantown, WV: Regional Research Institute Working Paper 9621, 1996.

Bureau of Labor Statistics. "How the Consumer Price Index Measures Homeowners' Cost." Report available at http://stats.bls.gov/cpifact1.htm. 1995. Carlino, Gerald, and Leonard Mills. "Convergence and the U.S. States: A TimeSeries Analysis." Journal of Regional Science 36(1996): 597-616.

Champernowne, David. "A Comparison of Measures of Inequality of Income Distribution." The Economic Journal 84(1974): 787-816.

Coughlin, Cletus G., and Thomas R. Mandelbaum. "Why Have State Per Capita Incomes Diverged Lately?" Review of the Federal Reserve Bank of St. Louis 70(1988): 24-37.

. "Have Federal Spending and Taxation Contributed to the Divergence of State Per Capita Incomes in the 1980s?" Review of the Federal Reserve Bank of St. Louis 71(1989): 27-42.

Dalton, Hugh. "The Measurement of the Inequality of Incomes." Economic Journal 30(1920): 348-361.

Deller, Steven C., Martin Shields and David Tomberlin. "Price Differentials and Trends in State Income Levels: A Research Note." The Review of Regional Studies 26(1996): 99-113.

Eberts, Randall W., and Mark E. Schweitzer. "Regional Wage Convergence and Divergence: Adjusting Wages for Cost-of-Living Differences." Economic Review (Federal Reserve Bank of Cleveland) 20(1994): 26-37.

Garnick, D.H. "Accounting for Regional Differences in Per Capita Income Growth: An Update and Extension." Survey of Current Business (January 1990): 29-40.

Garnick, D.H., and H.L. Friedenberg. "Accounting for Regional Differences in Per Capita Personal Income Growth, 1929-1979." Survey of Current Business (September 1982): 24-34.

Gastwirth, Joseph L. Statistical Reasoning in Law and Public Policy, Volume 2: Tort Law, Evidence and Health. Boston: Academic Press, Inc., 1988.

McCloskey, Deirdre N., and Stephen T. Ziliak. "The Standard Error of Regressions." Journal of Economic Literature 34(1996): 97-114. 
McMahon, Walter W., and Carroll Melton. "Measuring Cost of Living Variation." Industrial Relations 17(1978): 324-332.

Redman, J.M., T.D. Rowley and J. Angle. "The Role of Nonmetropolitan Economic Performance in Rising Per Capita Income Differences Among the States." The Review of Regional Studies 22(1992): 155-168.

Renkow, Mitch. "Income Non-Convergence and Rural-Urban Earnings Differentials: Evidence from North Carolina." Southern Economic Journal 62(1996): 1016-1027.

Theil, Henri. "The Development of International Inequality 1960-1985." Journal of Econometrics 42(1989): 145-155. 


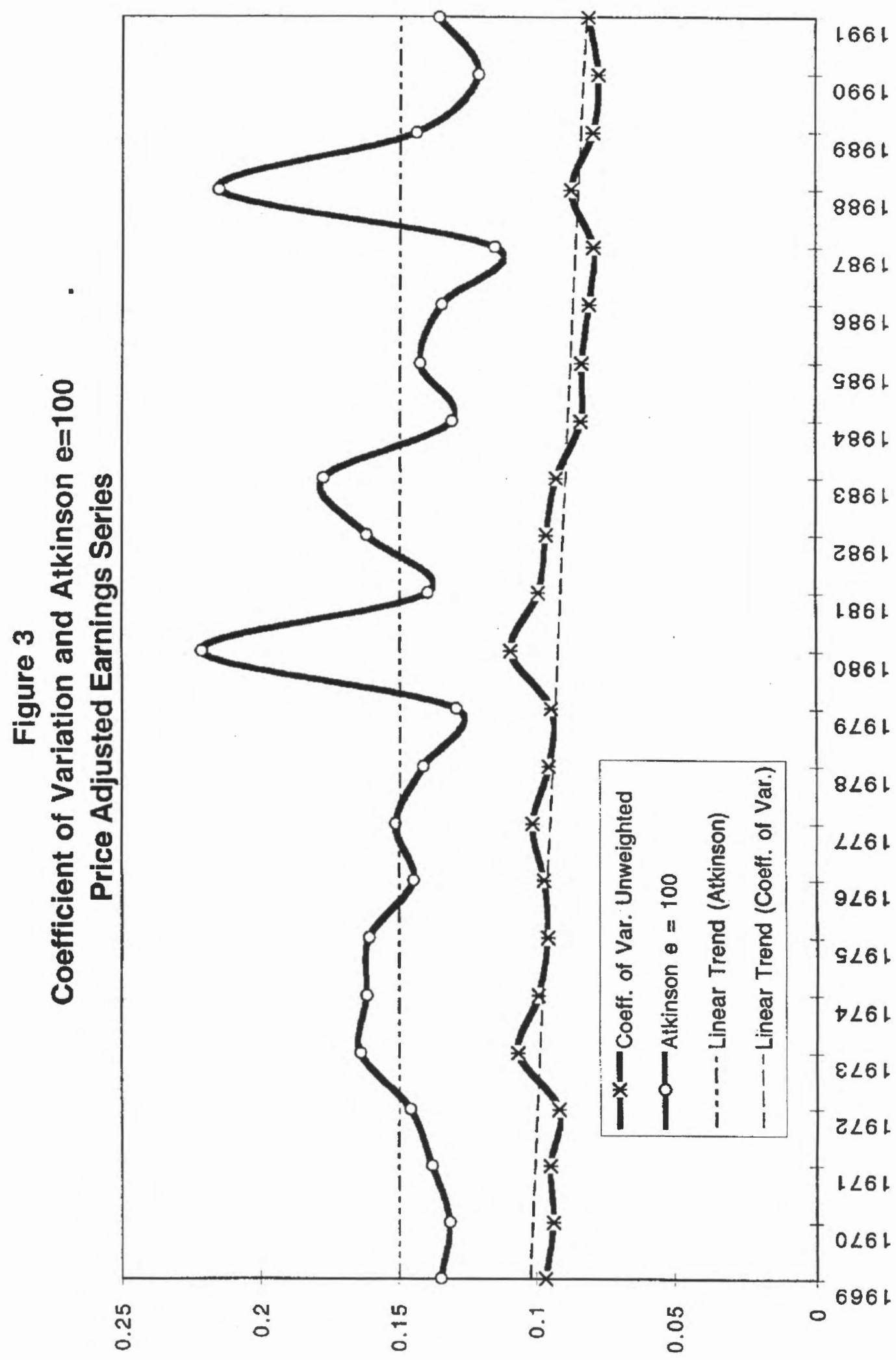


This result has important implications for the practice of using summary inequality measures to inform processes of income convergence. While the trend in the Atkinson index appears volatile, its linear trend is relatively flat, suggesting neither an increase or decrease in inequality. That is, poorer states are not catching up with richer states in terms of earnings per worker given that the Atkinson index with an inequality aversion parameter of 100 puts greater weight on the lower part of the distribution. However, the fact that the linear trend of the unweighted coefficient of variation displays a statistically significant negative slope does suggest a decline in inequality. In other words, when equal weight is attached to transfers across the entire distribution, the summary measure indicates a decline in inequality. Consequently, the convergence implication suggested by the coefficient of variation measure is nullified by the fact that poorer states are not catching up with richer states as suggested by the Atkinson index.

\section{CONCLUSION}

The Deller et al. article provides suggestive evidence that regional and temporal price adjustments substantially alter trends in state per capita income identified by commonly used summary measures. It thus provides a counter to previous analyses identifying a process of regional income divergence. In this paper we have attempted to demonstrate that the convention in the literature of relying on summary inequality measures is supported by very weak rules of evidence. More transparent results are available to the researcher using a simple tool of inequality analysis such as the Lorenz curve. The Deller et al. article goes on to suggest the policy implications of examining the price adjusted data regarding income inequality generally and the process of income convergence more specifically. This paper takes issue with the policy implications derived from the analysis. Specifically, the price adjusted analysis provides insights toward selecting more appropriate data to examine the income convergence hypothesis. In fairness to the Deller et al. article it should be noted that the literature they rebut has also accepted the per capita income measure as appropriate to address issues of regional convergence.

Reliance on a single summary inequality measure (Amos 1988, 1989; Coughlin and Mandelbaum 1988, 1989; Garnick 1990; Redman, Rowley and Angle 1992) - or even the construction of several of the most commonly used measures (Deller et al. 1996) —cannot provide 'clear and convincing' evidence of a pattern of increasing or declining inequality. The approach used in the Deller et al. article allows the authors to conclude that the pattern of increasing inequality in the 1980s disappears for four of the five popular inequality measures used in the literature they rebut after controlling for regional cost-of-living differentials. The approach does not allow a more general statement.

Our results suggest there is much to be gained by routinely examining Lorenz curves to determine if an unambiguous statement can be made and, if not, identifying those parts of the distribution commanding a lesser share of total 
income. Most importantly, the examination of Lorenz curves allows examining information from the entire distribution in a meaningful way-a rare opportunity in most empirical work. This is an important addendum to a debate meant to inform best practice in the analysis of regional inequality.

We have demonstrated that the policy implications from articles which either identify a process of divergence or convergence through the use of summary measures should be used cautiously for a number of reasons. There is no theoretical or empirical support for equating decreases in regional income inequality using summary measures with regional income convergence. The process of regional convergence requires that poorer states catch up with richer states. This may or may not be indicated by an overall decrease in income inequality. Yet, even if one does identify a genuine empirical process of income convergence, the question remains whether the data series used is appropriate to inform the capital deepening hypothesis of the theory. In the Deller et al. article, the argument that price differentials do matter raises questions as to the appropriateness of the total income measure for testing the theoretical basis of convergence through capital deepening. Our analysis of earnings per worker data suggests that the widely accepted process of income convergence over the 1970s may be a spurious result driven by unearned sources of income.

As a research note the Deller et al. article is effective in demonstrating that state price differentials do matter in the examination of regional inequality. In challenging the conventional presumption that these differentials can be disregarded, the article opens up the literature on regional convergence to productive criticism and prods regional scientists to develop more valid regional price indexes. It is in this same vein that this paper is directed. By using more transparent analysis of income inequality - thus replacing the reliance on summary measures which may mask important details-researchers will be motivated to ask tough questions regarding the observed trends. This same transparency is likely to raise questions as to the appropriateness of the various measures used. This can only increase the power of empirical tests confirming or disconfirming a theory of substantial policy importance.

\section{REFERENCES}

Abraham, Jesse M., and Patric H. Hendershott. "Patterns and Determinants of Metropolitan House Prices, 1977 to 1991." In Real Estate and the Credit Crunch, Lynn E. Browne and Eric S. Rosengren, eds. Proceedings of a Conference Held at Melvin Village, New Hampshire, sponsored by the Federal Reserve Bank of Boston, September 1992.

Allison, Paul D. "Measures of Inequality." American Sociological Review 43(1978): 865-880.

Amos, O.M. "Unbalanced Regional Growth and Regional Income Inequality in Latter Stages of Development." Regional Science and Urban Economics 18 (1988): 549-566. 
Amos, O.M. "An Inquiry into the Causes of Increasing Regional Income Inequality in the Latter Stages of Development." The Review of Regional Studies. 19(1989): 1-12.

Atkinson, Anthony B. The Economics of Inequality. New York: Oxford University Press, 1983.

. "On the Measurement of Inequality." Journal of Economic Theory 2 (1970): 244-263.

Barro, Robert J., and Xavier Sala-i-Martin. "Convergence." Journal of Political Economy, 100(1992): 223-251.

Blackwood, D.L., and R.G. Lynch. "The Measurement of Inequality and Poverty: A Policy Maker's Guide to the Literature." World Development 22(1994):567-578. Blanciforti, Laura A. "Estimating Interregional Price Indexes: Opportunities and Pitfalls." Morgantown, WV: Regional Research Institute Working Paper 9621, 1996.

Bureau of Labor Statistics. "How the Consumer Price Index Measures Homeowners' Cost." Report available at http://stats.bls.gov/cpifact1.htm. 1995. Carlino, Gerald, and Leonard Mills. "Convergence and the U.S. States: A TimeSeries Analysis." Journal of Regional Science 36(1996): 597-616.

Champernowne, David. "A Comparison of Measures of Inequality of Income Distribution." The Economic Journal 84(1974): 787-816.

Coughlin, Cletus G., and Thomas R. Mandelbaum. "Why Have State Per Capita Incomes Diverged Lately?" Review of the Federal Reserve Bank of St. Louis 70(1988): 24-37.

. "Have Federal Spending and Taxation Contributed to the Divergence of State Per Capita Incomes in the 1980s?" Review of the Federal Reserve Bank of St. Louis 71(1989): 27-42.

Dalton, Hugh. "The Measurement of the Inequality of Incomes." Economic Journal 30(1920): 348-361.

Deller, Steven C., Martin Shields and David Tomberlin. "Price Differentials and Trends in State Income Levels: A Research Note." The Review of Regional Studies 26(1996): 99-113.

Eberts, Randall W., and Mark E. Schweitzer. "Regional Wage Convergence and Divergence: Adjusting Wages for Cost-of-Living Differences." Economic Review (Federal Reserve Bank of Cleveland) 20(1994): 26-37.

Garnick, D.H. "Accounting for Regional Differences in Per Capita Income Growth: An Update and Extension." Survey of Current Business (January 1990): 29-40.

Garnick, D.H., and H.L. Friedenberg. "Accounting for Regional Differences in Per Capita Personal Income Growth, 1929-1979." Survey of Current Business (September 1982): 24-34.

Gastwirth, Joseph L. Statistical Reasoning in Law and Public Policy, Volume 2: Tort Law, Evidence and Health. Boston: Academic Press, Inc., 1988.

McCloskey, Deirdre N., and Stephen T. Ziliak. "The Standard Error of Regressions." Journal of Economic Literature 34(1996): 97-114. 
McMahon, Walter W., and Carroll Melton. "Measuring Cost of Living Variation." Industrial Relations 17(1978): 324-332.

Redman, J.M., T.D. Rowley and J. Angle. "The Role of Nonmetropolitan Economic Performance in Rising Per Capita Income Differences Among the States." The Review of Regional Studies 22(1992): 155-168.

Renkow, Mitch. "Income Non-Convergence and Rural-Urban Earnings Differentials: Evidence from North Carolina." Southern Economic Journal 62(1996): 1016-1027.

Theil, Henri. "The Development of International Inequality 1960-1985." Journal of Econometrics 42(1989): 145-155. 